\title{
Study on the problems and countermeasures of accounting in network economy \\ Yan Wang ${ }^{1, a}$
}

${ }^{1}$ School of finance and economics, dalian university of science and technology, dalian, liaoning, China

\section{a80773582@qq.com}

\section{Keywords: Network economy; Accounting; Enterprise}

\begin{abstract}
With the rapid development of network economy and continuous progress of science and technology, Internet technology and its popularization in various industries, accounting work has become more and more important.And with the rapid development of global economic integration, enterprises are facing new challenges and opportunities. The characteristics of openness, low cost and high efficiency of network economy make enterprises change their operation mode gradually, and make accounting better adapt to the development of network economy. This paper studies the reform of enterprise accounting, the development trend of accounting at home and abroad, the influence of network economy on accounting, the existing problems and the solutions.Enterprises under the background of the network is faced with new challenges and opportunities, benefits the Internet also has disadvantages at the same time, accounting is not a simple accounting tools, it has entered a new milestone.So enterprises should have a broader view of the development of accounting, the accounting simplification, make accounting repositioning, set new goals and sets up the new concept of risk, specific analysis.
\end{abstract}

\section{Introduction}

With the rapid development of network economy, accounting system plays an important role in information technology. The most obvious advantage is that the Internet economy is "fast". On the one hand, the speed of information transmission becomes faster, which makes the receiver of information receive information faster, greatly improving the work efficiency.On the other hand, the performance in information screening, processing and application, so that the work efficiency of accounting personnel has improved.Accounting have a significant impact on the survival and development of the enterprise, if the enterprise accounting information processing speed of lagged behind the development of market economy, will affect the development of the enterprise, the enterprise's market share and economic benefit is lower.Moreover, the development of accounting can not only ensure the sustainable and stable economic benefits of enterprises, but also help enterprises provide good development strategies.

\section{Theoretical basis of accounting in network economy}

\subsection{The meaning of network economy}

Network economy, seemingly simple four words but contain a lot of content.It is in the computer network, virtual currency and e-commerce, on the basis of the development of information technology as the core of an economy, the information economy and service economy very good fuses in together, in the perspective of economics, we for the development of social economy and innovation are described in a macro.

\subsection{The significance of accounting in network economy}

First of all, enterprises can find problems in a timely manner through enterprise accounting, so as to effectively strengthen the management level of enterprises.In the process of the accounting work, the enterprise can be relatively decentralized enterprise information summarized, including the 
accounting vouchers, accounting data, these material can well reflect the enterprise in the business management have not found the problem, the enterprise can timely and effective supervision, strictly according to the system to regulate the enterprise, and ensure the sustainable development of enterprises.Secondly, enterprise accounting is an important part of the construction of enterprise internal accounting responsibility system. This system mainly consists of three aspects: the general responsibility of the enterprise, the responsibility of the responsible person of each department and the responsibility of the enterprise accountant.Business operator responsibility refers to the main responsibility of product quality.

\section{Analysis of current situation of accounting under network economy}

\subsection{Impact on the accounting personnel}

Traditional accounting generally includes financial staff and cashier staff, but under the network economy accounting must increase network maintenance personnel and system management personnel.And as the business scope continues to expand, the requirements on the comprehensive ability of accountants are becoming more and more strict.Besides the basic accounting skills, we should also master computer technology and laws and regulations on e-commerce. Such comprehensive talents are still in short supply.

\subsection{Impact on the management of accounting records}

In practice, the accounting information of the application is very extensive, it can be accounting electronic information and timely accounting files stored in the storage, convenient for the supervision of the auditing department work.Because part of small and medium enterprises is value economic development, ignore the accounting information platform construction, lead to electronic management system lags behind, not timely application to the enterprise management, so improve the accounting of enterprises information construction is particularly important.

\section{Problems in accounting under the background of network economy}

\subsection{The security of the network accounting information system is poor}

First, the enterprise does not specify a specific solution, especially in the technical aspect of the blind area.For example, there are many ways for network viruses to invade, with various patterns and unexpected nature. It is hard to find them after the invasion.Faced with these problems, many enterprises do not know what measures to take to protect their information security.Second, enterprises in the security of the solution of the problem on the wrong. Some although formulated the plan of the enterprise, but by using some anti-virus product to solve, not from a fundamental aspects of prevention and cure, and ignore the change of network virus quickly, even some enterprises think as long as installed antivirus software will not be invaded, not timely maintenance to prevent system upgrade.

\subsection{Unclear accounting methods}

At present our country private enterprise on the management mode of ownership and management rights mostly are highly unified, corporate investors also serves as the role of operator, so the alone the right type of management mode, seriously affected the enterprise's accounting development.Investors and operators of enterprises are the same, and the public property of enterprises and the property of individual families are not clearly divided, leading to mutual use.Investors of the enterprise feel it is quite normal to invest and operate their own businesses. Accountants also employ people from their own families, and there is no supervision department, which directly leads to unclear use of funds.Due to the use of funds did not make clear a regulation, when companies appeared in urgent need of capital turnover to continue operating status, makes the enterprise management in crisis, and have serious impact on the sustainable development of the enterprise, greatly increased the workload of accountants. 


\subsection{The basic accounting work is not solid}

The function of internal accounting supervision is weakened.The internal accounting supervision function of enterprises is weakened due to the imperfect control system.If an enterprise wants to maintain the security and integrity of its property and establish an internal control system, it should entrust operation to supervise its property on the basis of the enterprise system.But many enterprise loophole in formulating rules and regulations, rules and regulations is not sound, lack of all kinds of supervision system, also did not establish the internal audit department, even at the very least, internal auditors are not set, there is not even the internal check system specification, sometimes even more perfect, but there was no implementation in the work, don't evaluation, as a decoration.

\subsection{The comprehensive quality of accounting personnel is low}

Compared to small and medium-sized enterprises and state-owned enterprises, financial personnel both knowledge level and comprehensive quality overall is low, cause there will be a lot of problems, such as enterprise financial work is not taken seriously, make accounting no in the enterprise is in place, managers lack the consciousness of financial management in accordance with the law, because of the lack of accounting personnel in terms of technology, economic matters agent and accounting personnel in accounting work and handle accounting matters, the business level is low, legal awareness is not strong, lack of professional knowledge, etc.

\subsection{Unclear boundaries of accounting subjects}

The division of management rights and ownership of small and medium-sized enterprises is not as clear as that of large enterprises.It often happens that personal property and enterprise property are confused with each other, and the boundary between personal property and enterprise property is blurred, which brings unnecessary troubles to the accounting work.

\section{Countermeasures of accounting problems in network economy}

\subsection{Establish accounting information system}

The main emphasis of accounting under network economy is the timeliness and validity of information.Enterprises should value accounting information technology management work, strictly in accordance with the accounting regulations and rules for implementation and management, establish information database platform, summed up the error-prone work item or work link, measures should be formulated.Communicate well with the operator and delegate technical decisions to the operator as he will generally have a better understanding.

\subsection{Strengthen the construction of internal control}

In dealing with matters of accounting accounting personnel, operation process and use of accounting information should be monitored at the same time record and timely backup jobs, do regular check, both to ensure that data is not leaked and loss also can guarantee the legitimacy of the information, to avoid the data is modified.

\subsection{Strengthen the training of online accountants}

It is an important part of the development of network economy to train the compound knowledge structure accountants and improve the ideological and moral quality of accountants. The development and competition of enterprises are at a disadvantage. To keep pace with the development of network economy, we still need the support of the state.Such as strengthening the education of accounting personnel, pay attention to this kind of talent cultivation and development, the rapid adjustment of accounting education system, reorganize the accounting personnel's knowledge structure, looking for update faster way of education.Attach importance to the continued education of accounting personnel, timely supplement the knowledge of accounting under the network economy, and strengthen the skills training of network accounting. 


\subsection{Clarify the accounting entity}

The definition of the main body of accounting means that there must be a clear definition standard for smes.And the standard that formulates should have clear division range, cannot appear the phenomenon that accountant main body confuses. The responsibilities and rights of each department within the enterprise shall be clearly divided, and the management system of responsibility system shall be established to make the responsibilities and responsibilities clear.Accounting executors, auditors and other positions have clear division of labor, which can improve the work quality of enterprises and promote the standardization and procedural accounting work.

\section{Conclusion}

The development of the Internet is a double-edged sword, and there will certainly be various problems to be overcome. However, as long as we work hard to find a solution and actively deal with it, we will certainly develop in a good direction. This paper analyzes the changes of accounting with the development of network economy and summarized, discussed the characteristics of the accounting problems and countermeasures, embodies the characteristics of diversified accounting computerization.It is hoped that we can put forward new ideas and better solutions to the problems in the accounting under the network economy.

\section{References}

[1] feng lian. A brief analysis of the impact of network economy on the development of accounting,Assets and finance of administrative undertakings, vol.21, pp. 85-86, 2014.

[2] han lei. The development and trend of accounting in the era of Internet economy, Modern economic information, vol.14, pp. 271, 2014.

[3] ge xuejie. The impact of China's value-added trade on employment, Anhui university of finance and economics, 2015.

[4] wei jiannan. On the impact of network economy on financial accounting, Modern economic information, vol.01, pp. 204-205,2016.

[5] li wenjing. Research on the influence of virtual enterprises on the four accounting hypotheses and countermeasures in the context of network economy, Brand (the second half of the month), vol.07, pp. 149-150,2015.

[6] zhang mingxuan. Study on accounting and financial treatment of Internet finance, China management informatization, vol.10, pp. 31-32,2018.

[7] fang wanting. Research on accounting issues in the Internet economy,China market,vol.13, pp. $39-40,2015$.

[8] yu ruyu. The influence of "Internet economy" on modern accounting ,Modern economic information, vol.22, pp. 119-120,2017.

[9] zhou ziyan. Discussion on the influence of network economy on financial accounting, Financial economy,vol.16, pp. 152-154,2017.

[10] cao kecheng. A brief analysis of the accounting development trend in the network economy,Economic research guide, vol.07, pp.110-111,2017. 